\title{
TRAVERSING SACRED STONES IN THE HEART OF BORNEO: TRANSBOUNDARY ECOTOURISM THROUGH THE MEGALITHIC LANDSCAPES OF THE KELABIT HIGHLANDS OF SARAWAK, MALAYSIA AND THE KERAYAN HIGHLANDS OF KALIMANTAN, INDONESIA
}

\author{
Sarah Hitchner* \\ Department of Anthropology, University of Georgia \\ Poline Bala \\ Institute of Borneo Studies, Univesiti Malaysia Sarawak \\ Corresponding author (*): Sarah Hitchner (slhitchn@uga.edu)
}

\begin{abstract}
The Kelabit Highlands of Sarawak, Malaysia and the Kerayan Highlands of Kalimantan, Indonesia are culturally contiguous areas separated by the Apad Wat mountain range, consisting of a number of villages that are related ethnically, linguistically, and through marriage. Though now separated by a political boundary, locals have always traversed this border. Now, foreign tourists also walk across this border, as community-based transboundary ecotourism is often centered around long-distance trekking among villages. The main attractions along the way for most tourists are impressive megaliths that include erected stones, carved stones, and large piles of stones, and other cultural sites such as old longhouse sites, and earthworks in various shapes such as crocodiles. These cultural sites, and the landscape in which they are found, represent a complex history of movement in the landscape by various, but related, ethnic groups that predates political separation. These sites have deep cultural and religious significance to local people on both sides of the border, and the experience of trekking among them has significance beyond mere tourism for many visitors as well. There is strong local, governmental, and international support for ecotourism development here, as well as an awareness of the possible pitfalls of expanding ecotourism in this region. This paper provides background on elements of the landscape itself, particularly megalithic structures located within intact rain forest, that attract visitors. It also presents a synopsis of some of the cross-boundary efforts to simultaneously promote responsible and culturally sensitive ecotourism development and to protect the ecological and cultural integrity of this unique megalithic landscape in the "heart of Borneo." Research for this article was conducted primarily in the Kelabit Highlands, and emphasis on this area is reflected in the data and discussion.
\end{abstract}

Keywords: Cultural landscapes, ecotourism, Kelabit Highlands, Kerayan Highlands, megaliths

Copyright: This is an open access article distributed under the terms of the Creative Commons Attribution-NonCommercialShareAlike 4.0 International (CC BY-NC-SA 4.0) license which permits unrestricted use, distribution, and reproduction in any medium, for non-commercial purposes, provided the original work is properly cited.

\section{INTRODUCTION}

The Kelabit Highlands of Sarawak, Malaysia and the Kerayan (also called Krayan) Highlands of Kalimantan, Indonesia are highland plateaus separated by the Apad Wat mountain range in interior Borneo. This area is included in the "Heart of Borneo," a term likely coined by Charles Hose in 1900 (Hose, 1900) and adopted by the high-profile transboundary conservation initiative led by the World 
Wide Fund for Nature (WWF). The Kelabit and Kerayan Highlands are home to several closely related ethnic groups (including Kelabit, Lun Dayeh/Lun Bawang, Berian, Lengilu, Sa'ban, and Penan) that speak related languages and have many cross-boundary kinship ties. They are as much part of the landscape as the forests, farms, rivers, and wildlife, hence call Heart of Borneo home. Shared cultural features include similar wet-rice cultivation techniques and handicrafts (such as beadwork and weaving of baskets and mats), as well as a common history of megalith-making activities. These megaliths, which include erected or carved stones, large rock piles, and other stones with associated myths, and other cultural monuments dot the landscape surrounding the rural villages and demonstrate the cultural contiguity of these plateaus, which are separated by a mountain range which takes most people about two or three days to cross by foot.

These close cultural ties between the Kelabit and Kerayan Highlands, in addition to cool temperatures and forests that have not yet been logged or converted to large-scale agriculture development, create an ideal situation for the development of community-based transboundary ecotourism initiatives that have the potential to be both a long-term source of revenue for rural communities and a land-use option that is compatible with local, regional, national, and international goals to conserve biodiversity and natural resources. Relatively uncommercialized, these villages allow for a more genuine cultural encounter than is possible in other places in Borneo that are promoted as tourism destinations (Zeppel, 1997), which are often heavily commercialized and, to a certain extent, "staged" (Din, 1997). This in itself presents a strategic asset of singular long-term socio-economic and cultural importance to the area. Based on numerous discussions with guides, homestay owners, and tourists who visit the highlands of Borneo over a period of several years, it is clear that tourists visiting interior Borneo prefer local homestays over hotels and resorts, and that they seek adventurous jungle trekking with local guides instead of predictable, pre-packaged vacations.

This paper examines transboundary ecotourism development in the Kelabit and Kerayan Highlands; emphasis is on the Kelabit Highlands of Sarawak, as research for this case study was conducted primarily here by two cultural anthropologists, one (Poline Bala) a member of the Kelabit community. The data presented here are based on observations, encounters, and research collaborations we have had through our separate Ph.D. research experiences in the Highlands. These data include extensive interviews with Kelabit community members, including elders, leaders, and guides and homestay owners, as well as tourism and heritage preservation professionals in Sarawak and foreign visitors to the Highlands. Though the authors were doing two different research projects in different times, these projects were interrelated in some ways as the Highlands were going through an unprecedented encounter with the "outside" world, especially with the encroachment of logging and the creation of a new national park (Pulong Tau National Park) which encompassed much of the Kelabit Highlands. Increased awareness of the existence of historical monuments and new ideas influencing the trajectory of development in the Highlands demanded that the communities think through their own responses. Community-led efforts to develop and promote transboundary ecotourism have resulted as local communities in the Kelabit and Kerayan Highlands (see Figure 1) have transformed economic, social and cultural assets; these include the geophysical landscape and its man-made features, as well as historic trade routes and kinship connections that for generation have linked these communities 


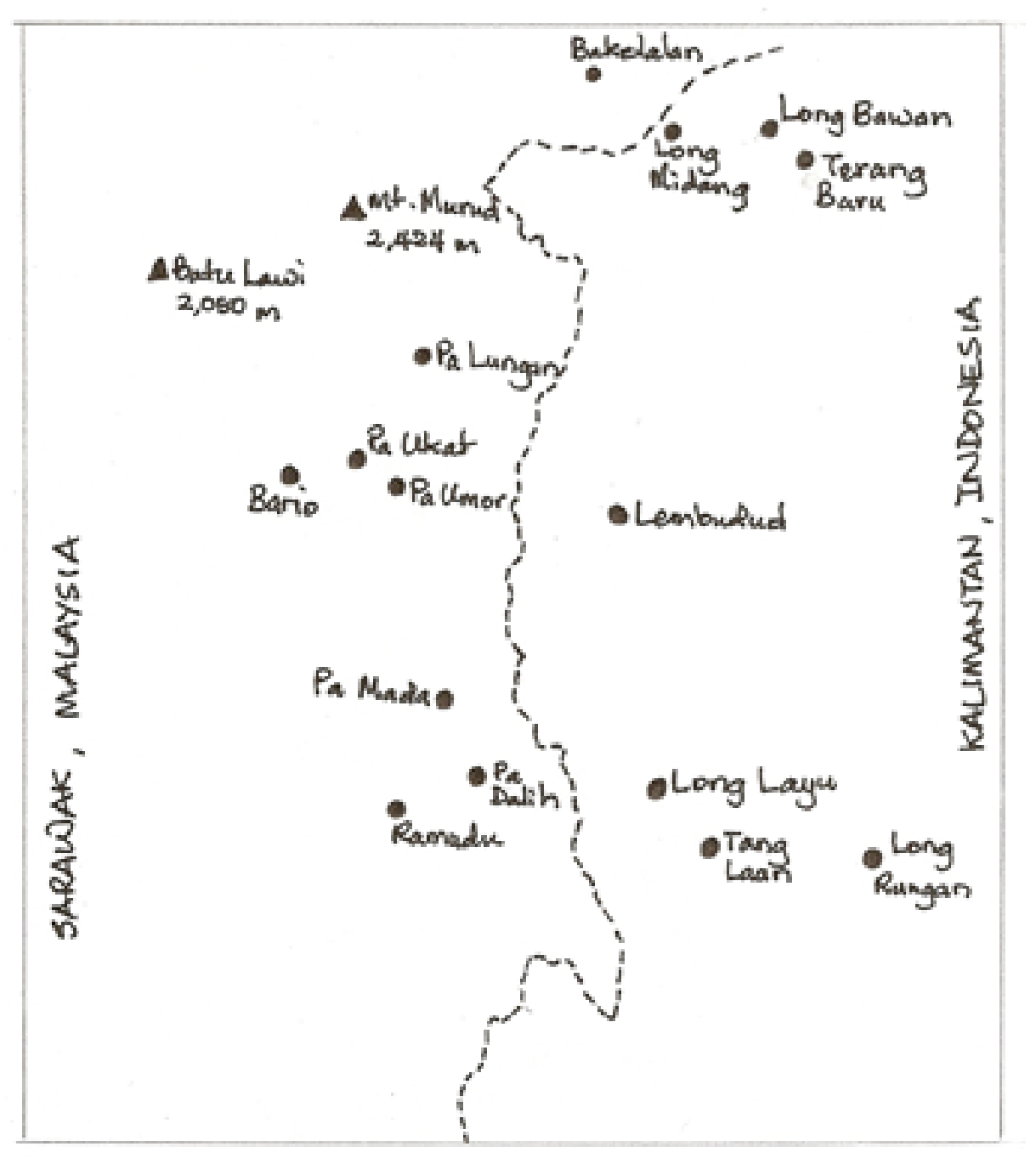

Figure 1: Villages in the Kelabit Highlands of Sarawak and the Kerayan Highlands of Kalimantan (Credits: map by Florance Lapu Apu, original publication in Hitchner, S. et al., 2009).

First, we will provide a brief overview of the cultural history of the area, emphasizing the origins of the Kelabit people and the cultural links with people currently living in Kalimantan (see Bala, 2002 for a more thorough examination). Then we will describe the cultural landscape and some of the main tourist "attractions" in the forms of megaliths associated with Kelabit ancestors, spirits, and mythological figures and events. We then provide a synopsis of ecotourism in the Heart of Borneo, with an emphasis on Malaysia. We follow by describing various local organizations that promote, administer, manage, and monitor ecotourism on both sides of the border. Finally, we conclude by referencing some of the main challenges posed by local communities in offering tourists an "authentic yet curated" experience in this highly anthropogenic landscape of interconnected communities.

\section{BACKGROUND: KELABIT ORIGINS AND CULTURAL CONTIGUITY OF THE KELABIT AND KERAYAN HIGHLANDS}

The area generally known as the Kelabit Highlands is situated on a plateau in interior Borneo in Sarawak, and it includes about $2500 \mathrm{~km}^{2}$ of land (Sidu, 2007). The Kelabit Highlands are bounded by the Tama Abu mountain range on the west and northwest, which include a series of ranges running north-south (Singh, 1998), and on the east by the Apad Wat (literally "apad," meaning "mountain range," and "wat," meaning "tree roots"), which divides the Kelabit Highlands of Sarawak from the Kerayan (also spelled Krayan) Highlands of Kalimantan (Bulan, 2003; Ardhana et al., 2004). The Kelabit are a small ethnic 
group from the interior of Borneo in northeastern Sarawak. They number about 5000 total, though only about 1200 live in the Kelabit Highlands today. The Kelabit are closely related linguistically and culturally to the Lun Bawang, Lun Berian, and Lun Kerayan (Eghenter and Langub, 2008; Bala, 2002; Langub, 1987; Zainuri, 2018). Bala (2002) notes that these groups share a common history but were separated by sociopolitical processes. "For instance," she writes, "oral traditions indicate that the Lun Kelabit, Lun Kerayan and Lun Bawang were one people, but were separated and then labeled with different names for administrative convenience by the colonialists" (Bala, 2002, p. 19). Among the Kelabit, "the people from the Berian area are referred to as Lun Berian, and the people from the Kerayan as Lun Kerayan, while the people from the Trusan, Ba' Kelalan, Lawas areas as Lun Bawang” (Bala, 2002, p. 22).

Some Kelabit and scholars of Borneo history say that the Kelabit people now occupy the highlands because they were originally from lowland areas and were pushed there by other ethnic groups. Other references put the origins of the Kelabit people in what is now Indonesian Kalimantan (Mjöberg, 1925; Douglas, 1912). Kelabit scholar Yahya Talla (1979, pp. 17-18) provides evidence from Kelabit oral histories, legends and songs "which relate the origin of the Kelabit to the Brunei and Brunut valleys of present-day Brunei." He suggests that some Kelabit "migrated from Brunei up the Limbang River and into the Adang Valley:" then were pushed by Kayans to various areas, including the Leliu Plains, the Kayan and Mentarang valleys, the Trusan valley, the Tinjar and Tutoh Rivers, and Sabah. But many Kelabit say that they have always occupied the Kelabit Highlands area, even relating stories about how all humans originated in the Kelabit Highlands. Kelabit scholars have collected and analyzed their own oral histories, and the conception of the Kelabit Highlands as the ancestral homeland of the Kelabit people is central (Saging and Bulan, 1989). Talla (1979, p. 13) notes that "The origin of the Kelabit is a matter of anthropological speculation. The Kelabit themselves believe that they have roamed the Highlands from time immemorial."

It is likely that historically, Kelabit groups inhabited a much larger area than the Kelabit Highlands, and that there were (and still are) "Kelabit" villages in both upland and lowland areas. Ongoing research in the southern Kelabit Highlands suggests that "there seems every reason to believe that human occupation in the Kelabit Highlands stretches far beyond the Metal Age, the beginning of which in Borneo is commonly dated to between c. 500 BC and AD 0" (Barker et al., 2008, p. 179). Whether those humans were all people that would now be considered Kelabit is also a source of speculation; it is possible that they were Ngurik (or Ngorek, Ngurek or Murik) (see Mashman, 2017, Sellato, 2016), a small subgroup of Kenyah (Jalong, 1989), though Rousseau says that "the ancestors of the present-day Murik were Kelabitic" and that their language is considered Kayanic (Blust, 1974). What is not contested is that Kelabit now consider the Kelabit Highlands to be their homeland, despite the conflicting speculations on their origin, and the cultural contiguity with the Kerayan Highlands across the Indonesian border in Kalimantan.

\section{CULTURAL LANDSCAPE MODIFICATIONS IN THE INTERIOR HIGHLANDS OF BORNEO}

While much of interior Borneo may appear to outsiders as "untouched," numerous cultural sites are still visible in the landscape, and they have deep cultural significance of them to people living in these areas today (for more in-depth recent descriptions of these sites see Hitchner, 2008, Hitchner et al., 2009; Bulan, 2003; Sellato, 2016; Gani, 2019, and historical descriptions such as Schneeberger 1945; Keith 1947; Harrisson, 1958a, 1958b, 1959, 1962, 1973). Although the area of Kelabit Highlands, on the Malaysian side of the international border, is relatively small in size $\left(\sim 2500 \mathrm{~km}^{2}\right)$, as is its population $(\sim 1500)$, this landscape is highly anthropogenic and contains a substantial number of megaliths, landscape modifications, and other cultural sites. Although megaliths can be found in Indonesian Kalimantan (made by groups closely related to Kelabit), and to a lesser degree in the Sarawak River delta area and in Sabah (Sellato, 2016; Phelan, 1997; Harrisson, 1958b; Keith, 1947), the area of the Kelabit Highlands contains a particularly dense assemblage of megaliths and has been called a "megazone of megalithic activity" (Harrisson, 1959, p. 14). The megaliths in the Kelabit Highlands of Sarawak and the Kerayan Highlands of Kalimantan resemble those in other areas of Southeast Asia, 
including Peninsular Malaysia, particularly in Malaka and Negri Sembilan (Harrisson, 1958; Harrisson, 1962), and on the Indonesian islands of Java and Sumatra (Von Koenigswald, 1962), and there are also similarities to megaliths in Europe, Melanesia, and other parts of Asia (Eliade, 1979). However, megalithic activity in interior Borneo is most likely an isolated cultural phenomenon, without direct influences from outside cultural groups (Harrisson, 1958, p. 133).

By 2005, the Kelabit community was keenly aware of the importance of documenting cultural sites in the landscape. Some of these sites included: megaliths such as binatuh (graveyards); lungun belanai (grave sites with Chinese burial jars); batuh nawi (hollowed stone burial urns); landscape modifications such as kawang (notches cut into tree lines on ridge tops), nabang (ditches cut into the ground or through ridge tops), taka (oxbows of rivers); ruma' ma'un (old longhouse sites); and other areas of cultural importance such as main tudtu' (salt springs), rupan (swampy areas where animals come to drink), ra'an (mountain passes), and lubang (caves); and megalithic structures which are a distinctive feature of Kelabit culture, such as batuh sinuped (menhirs or erected stones), batuh narit (carved stones), batuh nangan (dolmens or stone "tables"), and perupun (large rock piles) (see Bala, 2002; Bulan, 2003; Hitchner, 2009a, 2009b, 2010; Janowski \& Barton, 2012; Jones et al., 2016). Archeologist Lindsay Lloyd-Smith notes that recent findings about megalithic monuments in the Kelabit Highlands "seem to indicate a widespread cultural tradition that flourished around 2,000 years ago, during the Early Metal Age" (cf. Coates, 2014, p. 57).

Here we provide a few examples of megaliths that exemplify the cultural history embedded in these stones. Batuh sinuped range in size from less than a meter tall to over two and a half meters tall. Most are rectangular in shape, wider than they are thick, with tapered or triangular tops. The stones used to construct them are usually found at the nearest river, although in some cases, the origin of the stones is unknown. They were made for many purposes, including to honor certain people (they were often erected in pairs symbolizing a husband and wife), as boundaries between villages, or to mark personal rites of passage (Labang, 1962; Harrisson, 1958b). Batuh narit are stones that have been carved with a design of some kind. Sometimes, these designs are carved in raised relief, so that the design stands out from the rest of the stone, while others are carved in sunken relief, so that the design is incised into the stone. Several recurring designs include animals such as gibbons, buffalos, hornbills, or dogs, as well as spread-eagle human figures (see Figure 2). Batuh nangan are "supported stones" or dolmens that range in size from quite small and close to the ground, to taller than a person and made of enormous stones. Batuh Ritung (Figure 3) in Pa' Lungan is especially large, with a massive flat capstone (over four meters long and three meters wide) raised on top of the pillars. Batuh Ritung is now protected by the Sarawak Museum under the Sarawak Cultural Heritage Monument Ordinance of 1993, and the area around it is fenced to protect it from damage from buffaloes. Batuh baliu ("transformed stone") appear to be natural stones, but according to Kelabit legend, they were once buildings that have turned to stone, as a result of people breaking taboos, such as laughing at animals. For example, Batuh Baliu Apad Runan in Pa' Di' it (Pa' Dalih) was once a longhouse. It is said that a woman named Runan once tied bells to a frog; when she did this, the people laughed and the longhouse was turned into stone by offended spirits. 


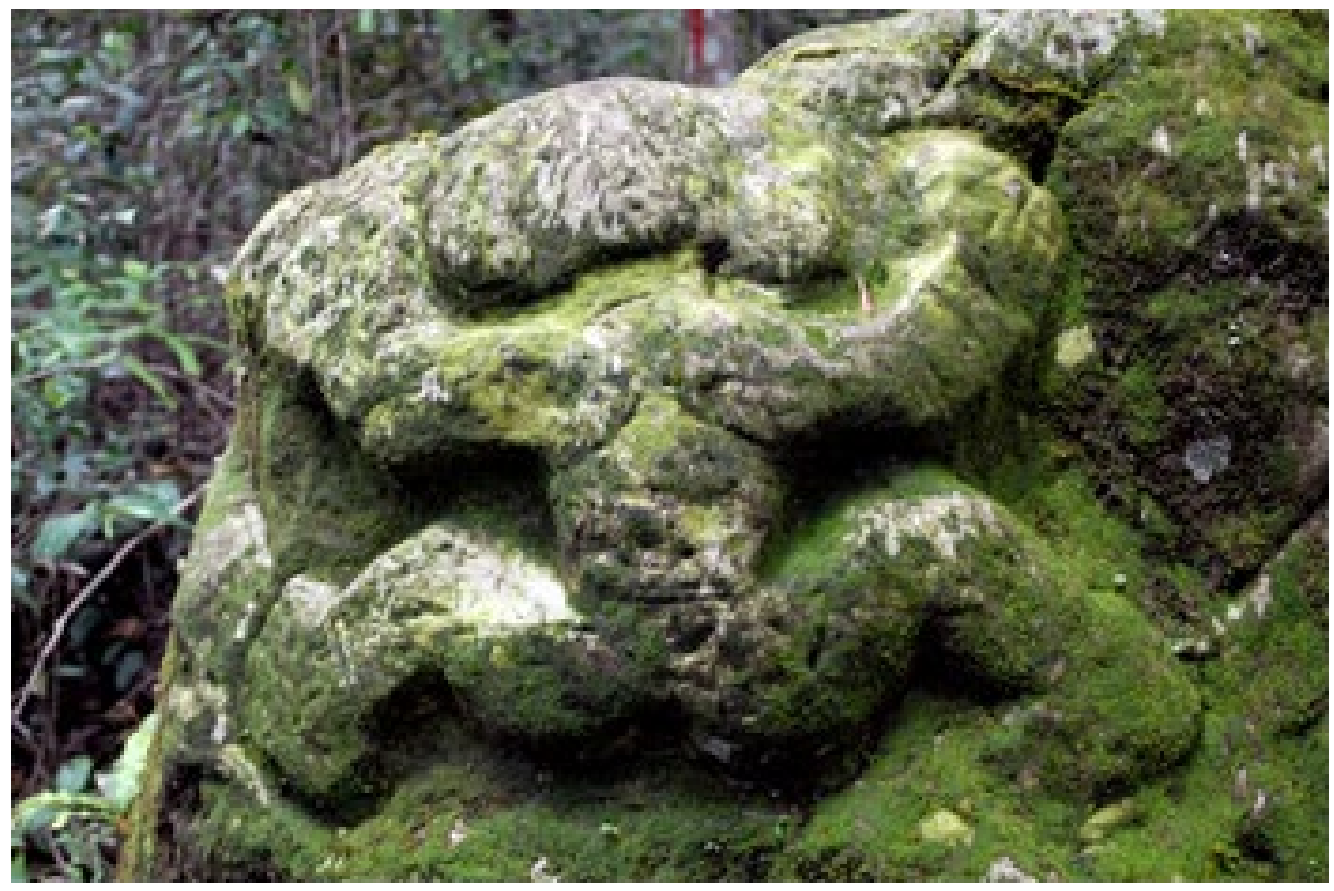

Figure 2: Batuh Kalabat in Batu Patong (Kelabit Highlands, Sarawak)

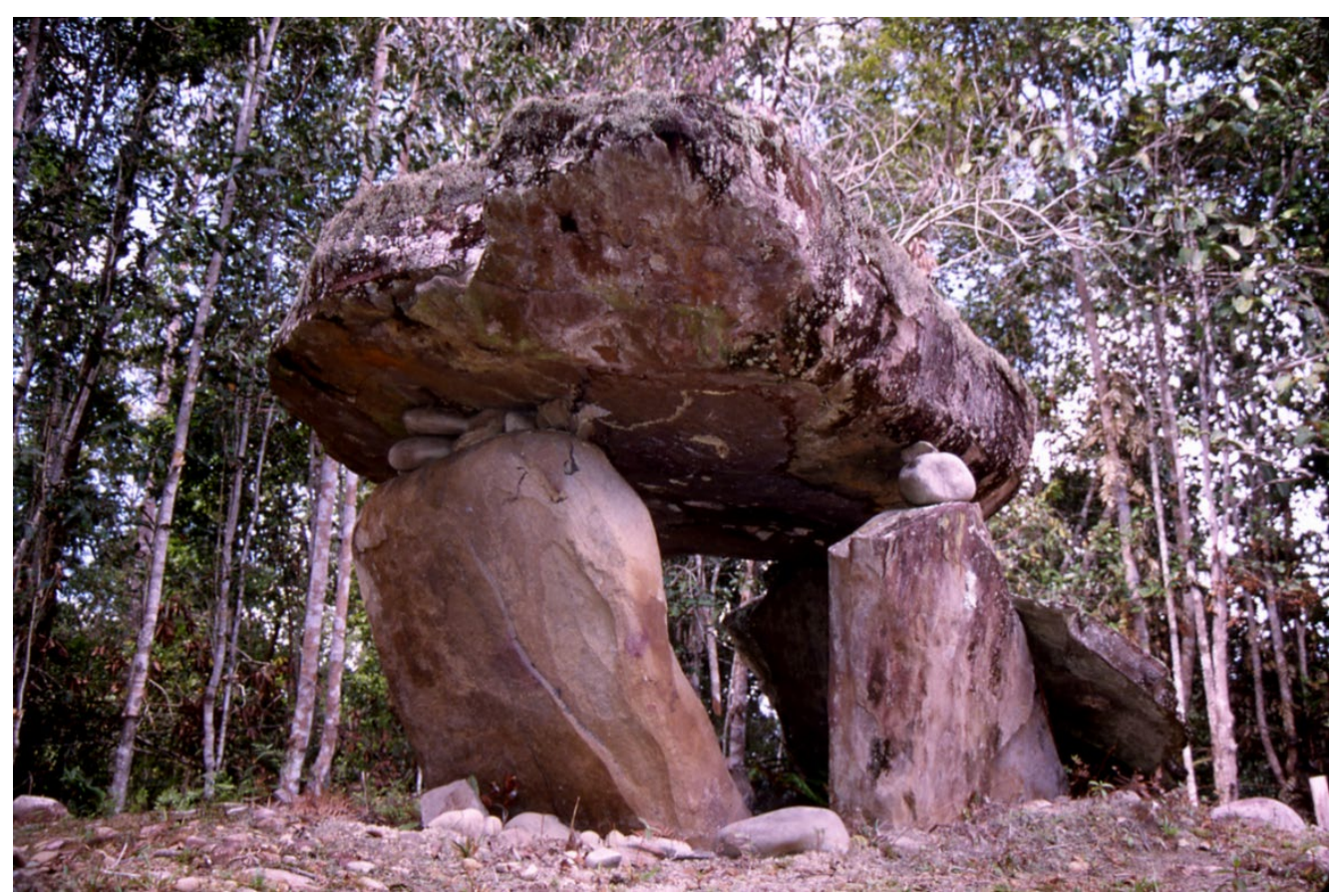

Figure 3: Batuh Ritung in Pa' Lungan (Kelabit Highlands, Sarawak)

There are other stones (sometimes large rock formations, almost small mountains) that appear to be natural, but according to Kelabit legend, are not quite natural. In Pa' Mada, there is a stone called Batuh Bulan, from which it is said that Tuked Rini, a supernatural being, used to bathe; apparently there is an impression of his loincloth on the stone. However, the stone has sunk into a padi field, and no one knows exactly where it is now. Another interesting "natural" stone associated with Tuked Rini is Batuh Tuked Rini Long Tekuyang / Batuh Sida'an Tuked Rini in Ramudu. This stone, a flat stone in the river, has a row of indentions that are exactly the size and shape of average human footprints. It is said that Tuked Rini stepped on this rock and that his supernatural powers burned his footprints into the stone. 
Here it is important to note that most Kelabit people are now Christian and may not recognize the landscape as "sacred" in the sense that it is currently animated by the spirits they once revered and feared, and with whom they coexisted (Hitchner, 2009). They feel freed by Christianity from their former animistic beliefs, framed now as "superstitions" (Amster, 2009, p. 313). Now, Kelabit believe the stories are important to preserve, as are the landscapes they inhabit, because these are lands that were given to them as a gift from God, and they are the stewards responsible for their preservation. Amster (2009) writes about how some sites in the Kelabit Highlands, such as the summit of Mount Murud, the highest peak in Sarawak, have become pilgrimage sites, and how multi-day church services on its slopes contribute to "local landscapes reinfused with new meanings in Christian terms" (Amster, 2009 , p. 308). Though the terms and understandings of the creation of the landscape have shifted, the responsibility to care for it remains.

Local communities (Lun Bawang, Lun Kelabit and the Lun Berian) on both sides of the border are working toward this goal of stewardship through various transboundary initiatives and mechanisms amongst themselves and also through networking and collaborating with outside governmental agencies, non-governmental organizations, research institutions, and others. In this paper we focus on the transboundary ecotourism initiative in the interior highlands of Borneo, as it binds together issues of indigenous identity, mobility, and agency. While all historical and modern human modifications of the landscape are important to document, here we place emphasis on the megaliths because they serve as metaphorical "stepping stones" across this landscape, as they are both physical incarnations of the cultural contiguity of the Kelabit and Kerayan Highlands and main attractions for tourists visiting this geographical area (see Lonely Planet, 2020).

\section{A BRIEF HISTORY OF TRANSBOUNDARY ECOTOURISM IN BORNEO}

Ecotourism in developing countries rich with natural and cultural capital is often promoted as a sustainable source of revenue for indigenous and rural communities, as well as a mechanism for the enrichment of local culture through contact with outsiders, and the revitalization of local cultural traditions (Mowforth \& Munt, 1998). However, it can also lead to ecological damage, haphazard infrastructure development, commercialization of culture, and exacerbation of inter- and intracommunity tensions (Carrier \& Macleod, 2005; West \& Carrier, 2004; Reed, 1997; Richter, 1989; Yacob et al., 2007; Mohamed, 2002; Chin et al., 2000). Many scholars, human rights advocates, and tourism practitioners have argued that in order to address these issues of inequalities created or reinforced by tourism in rural areas, it is important that local communities are active stakeholders in tourism ventures and that such ventures are not imposed on them by outsiders who seek personal gain (King, 1993; Stronza, 2005; Scheyvens, 1999; McLaren, 1997). However, this can be difficult and problematic on the ground, particularly when multiple communities are involved (Suich, 2008). The local communities in the Kelabit and Kerayan Highlands, both of their own initiative and with the assistance of international organizations, have implemented several strategies for maintaining local control of tourism and promoting and improving community-based transboundary ecotourism through the transboundary "Heart of Borneo" which includes national parks in both Sarawak and Kalimantan.

Led by the World Wide Fund for Nature (WWF), the Heart of Borneo is a large-scale, tri-national transboundary initiative that aims to tie ecological conservation with sustainable development in the geographical "heart' of Borneo (approximately 2.5 million hectares). Signed by the governments of Indonesia, Malaysia, and Brunei in 200733, the official Heart of Borneo Declaration (WWF-Denmark,

\footnotetext{
${ }^{33}$ In addition to state and national ministries and governmental agencies in Malaysia and Indonesia, a number of international conservation, development, and finance NGOs and agencies are directly and tangentially involved in the Heart of Borneo initiative: World Wide Fund for Nature (WWF), The Nature Conservancy (TNC), Conservation International (CI), the World Conservation Union (IUCN), Global Environmental Facility (GEF), Wildlife Conservation Society (WCS), International Tropical Timber Organization (ITTO), United States Agency for International Development (USAID), United Nations Development Programme (UNDP), United Nations Educational, Scientific, and Cultural Organization (UNESCO), the World Bank (WB), International Monetary Fund (IMF), Asian Development Bank (ADB), International Finance Corporation (IFC), and Association for East Asian Nations (ASEAN).
} 
2006) recognizes that the area is globally important and ecologically and culturally unique and serves as a repository of numerous endemic and endangered species, a source of watersheds for the entire island, and home to a number of indigenous communities who have managed this landscape sustainably for generations. Local livelihoods, centered on income from organic rice production and ecotourism, are dependent on intact forests and watersheds; simultaneous concern for local economies and protection of ecosystems and watersheds are evident in the planning for two national parks included in the Heart of Borneo: Kayan Mentarang National Park (KMNP) in Indonesia, which includes much of the Kerayan Highlands, and Pulong Tau National Park (PTNP) in Malaysia, which includes much of the Kelabit Highlands (Hitchner, 2010; WWF-Denmark, 2006). However, government agencies and private sector companies in both Malaysia and Indonesia are planning different scenarios for this area: expansion of protected areas, continued logging, large-scale agricultural development, increased smallholder agriculture, infrastructure and ecotourism development, and creation of income opportunities for local communities. These different scenarios would have substantial impacts on the future of ecotourism in the interior highland areas of Borneo.

While ecotourism is often proposed as an economic investment in conservation, visitor impact assessment is vital to simultaneously maintain ecosystem health and community control in areas that host ecotourism. This is particularly important in ecosystems as fragile as those found within the highland plateaus of interior Borneo, and for local communities that reject the commodification or objectification of their material culture, as is the case here. According to Din (1997), the objective is to balance the needs of the guests and the hosts, and to allow the local communities to define their priorities. He says (Din, 1997, p. 116): "For Malaysians, it is important that tourism will not jeopardize the societal goals that the host community defines."

In the case of the Kelabit and Kerayan Highlands, most community members agree that their main goals are conservation and development through their own local initiatives, and they see ecotourism as an important means of achieving these goals simultaneously. Due to the remoteness of this area, so far there has been little threat of the imposition of commercialized tourism on these communities, so it has remained in the hands of the community members. This could change in the near future, however, as the highlands become more accessible by roads and more infrastructure is developed by the government and the private sector. Community members have taken important steps to improve the quality of the ecotourism experience for visitors, to monitor and protect the natural and cultural resources in their villages, to expand the direct benefits of ecotourism to more community members, and to maintain control over the pace and course of ecotourism development in the geographical and metaphorical "Heart of Borneo." One major component of this community-driven ecotourism initiative is documenting cultural landscape modifications, in particular megaliths, as these are main attractions for tourists. This process of documentation also serves as a cultural and historical record for the communities and can be used in courts as evidence of historical occupation for claims of native customary land.

\section{CURATING THE TOURIST EXPERIENCE: LOCAL CONTROL OF ECOTOURISM}

While some tourists to the "Heart of Borneo" area are purely seeking recreation and diversion from daily life, most are also seeking authentic and immersive experiences in another culture. Most homestay owners and guides agree that overall, visitors interested in long-distance, transboundary trekking, are genuinely curious and try to be respectful, by considering and treating the highlands as cultural homelands and forested highland catchment areas. As visitors traverse a route with local guides through a landscape that is divided by political boundaries yet connected by culture, language, and familial relationships, they have transformative experiences that can have profound impacts on other aspects of their lives, including renewed dedication to environmental causes in their home countries (Hitchner et al., 2009).

In order to examine what happens "behind the scenes" to make these experiences possible, we look behind the veil to the political institutions and international efforts that enable and facilitate transboundary ecotourism, and to the agency exhibited by local communities and local individuals to 
maintain control of the impacts of ecotourism. Several local organizations, described below, are actively engaged in promoting, monitoring, and improving transboundary ecotourism in the Kelabit and Kerayan Highlands.

Rurum Kelabit Sarawak (RKS) is a local institution working on community and state levels dedicated to representing Kelabit people and improving the lives of both urban and rural Kelabit. It was formed in early 1991 as a response to the multiplicity of Kelabit associations functioning simultaneously throughout Sarawak. Tan (1994, p. 134) suggests that while the "emergence of six Kelabit associations" reflected the "internal differentiation and alignment" of urban Kelabit, it also showed "a certain lack of unity among the Kelabit." RKS was formed as an umbrella organization in the hopes of unifying the Kelabit. Consisting mostly of urban, wealthy, well-educated Kelabit (or formerly urban Kelabit who have since retired in the Kelabit Highlands), RKS is responsible for many of the processes of negotiations regarding the current situation in the Kelabit Highlands and the possible futures for it. They work closely with government agencies and non-governmental organizations planning projects for the Kelabit Highlands regarding conservation, agriculture, development, and tourism. The RKS leadership serves as a political link and conduit of information between the urban and rural Kelabit populations and currently manages the data resulting from efforts to map cultural sites such as megaliths.

The Tourism Bureau of the Kelabit Highlands is a committee under the larger unit of local development, The Bario Village Development Security and Health Council (known also as the JKKK Induk Bario). The mission of the council is the "mobilization and co-ordination of local tourism committees for accommodation providers, guides, porters, produce growers, handicraft artisans, sales outlets, catering operations, tea shops and local flora and fauna experts" (Harris, 2002). The Tourism Bureau oversees tourism development in the Kelabit Highlands and supports further ecotourism development, as well as enhanced international cooperation with the villages in the Kerayan Highlands.

The Bario-Ba' Kelalan Guide Association was formed in 2006. According to Sarawak state law, local tourist guides must be certified and licensed by the Ministry of Urban Development and Tourism. Until recently, no guides in the Kelabit Highlands were licensed, due to both ignorance of this law and the inconvenience and prohibitive cost of attending a training course held elsewhere in the state (RM3,0004,000 plus travel costs). Finally, due to pressure from the Kelabit guides, in September 2006, the Borneo Tourism Institute of Sabah and the Ministry of Urban Development and Tourism of Sarawak cosponsored a 16-day training workshop for guides in the Kelabit Highlands and Ba' Kelalan (a village north of the Kelabit Highlands, also in Sarawak). This workshop, resulted in the certification and licensing of 21 guides from the Bario area and six guides from the Ba' Kelalan area, as well as Sarawak Eco-Host certification for some homestay owners. The Guide Association is the primary acting agency in the Kelabit Highlands for addressing the challenges of transboundary ecotourism development, including promoting trekking options, building and maintaining jungle trails, and organizing the onthe-ground demarcation of cultural sites in the Kelabit Highlands.

Lembaya Swadaya Masyarakat (LSM) Tanah Tam ("Our Land") is an Indonesian NGO formed in the early 2000s. In 2002, a community-based ecotourism project was initiated in three communities in the Kerayan Highlands of Kalimantan, Indonesia (Long Rungan, Pa' Upan, and Long Layu'), in response to community concerns regarding long-term income generation from tourism and sustainable management of local resources. WWF-Indonesia assisted with funding and implementing this project, which included training, local capacity building, and cross-border visits to communities in Sabah, Malaysia that have been developing community-based ecotourism. In 2003, the local ecotourism committee gained the status of an NGO. Tanah Tam, an inter-community organization with committees in each village, works with community organizations in the Malaysian states of Sabah and Sarawak, as well as the local Tourism Office (Dinas Pariwisata dan Kebudayaan), to develop transboundary ecotourism options and ensure that control over the direction of ecotourism development remains in the hands of local community members.

FORMADAT, or Alliance of the Indigenous People of the Highlands in the Heart of Borneo (Forum Masyarakat Adat [Asli] Dataran Tinggi Borneo), is a transboundary community-based organization led 
by village headmen. It was officially established in 2003 with the financial and organizational assistance of WWF-Indonesia, although meetings among the various headmen in the highland communities have been taking place since the year 2000, under the organization's former name of FoMMA, or the Alliance of the Indigenous People of the Kayan Mentarang National Park (WWF-Denmark, 2006). The main communities involved in the FORMADAT are the Bario Highlands (including nine main villages, from Pa' Lungan in the north to Pa' Dalih and Ramudu in the south), Ba' Kelalan, Long Semado, Long Pasia, Long Bawan, Long Mio, Ulu Padas, and Long Layu'. Their mission is to: "increase awareness and understanding about the highland communities, build local capacity, and encourage sustainable development in the Heart of Borneo," and several specific issues they focused on in past meetings have been conservation, agroforestry, organic farming, and transboundary ecotourism. In 2015, FORMADAT (2020) won the UNDP Equator Prize, which recognizes outstanding achievements in preservation of natural and cultural resources and fostering resilient communities. Their website notes that: "Besides sustainable rice farming, FORMADAT and its partners are also advocating for sustainable ecotourism activities, which among others, resulted in a series of community land-use zoning activities and capacity building workshops for villagers to identify potential areas for tourism and improve local guides' competency."

\section{CONCLUSION}

For tourists, long-distance trekking across international boundaries in the "Heart of Borneo" presents physical challenges, logistical considerations, flexibility in planning, and, ideally, a high degree of cultural sensitivity. For local communities, it presents opportunities to simultaneously protect natural resources, provide income for community members, and serve as further incentive to document the boundaries of their land and the important and unique monuments within them. The megaliths and other monuments, while only one aspect of a highly anthropogenic landscape, continue to serve a vital role in Kelabit culture and identity. Coates $(2014$, p. 61) writes that: "Ties to the ancestral past, imprinted in stone and carved into the land, still bind the Kelabits today." These stone monuments in the Kelabit Highlands and the Kerayan Highlands may be an attraction for tourists, and many local community members are happy to share stories about them; however, they hold deep significance to local people that transcends curiosity, and preservation of them is dependent on preservation of the landscapes in which they are embedded.

However, as noted by Hitcher et al. (2009), local community members involved in ecotourism expressed the need to address several issues: 1) protection of forests and cultural sites as foci for ecotourism; 2) improved communication between villages, guides, and lodges; 3) increased promotion of transboundary trekking options; 4) village-level preparation for more tourists and more equitable distribution of income generated from ecotourism; 5) careful improvements in tourism infrastructure; 6) the negotiation of legal complications arising from international border crossings by tourists and guides; and 7) the maintenance of local control over ecotourism management and of the trajectory of future tourism development in the "Heart of Borneo." To date, many of these have improved through increased infrastructure development such as improved communications via internet and wireless telephone connections and the creation of drivable roads between villages. More homestays have opened to the public, especially as a number of retired community members have returned home to their villages and opened their homes to visitors.

Community members have offered more visits to cultural sites, especially megaliths, to tourists expressing a desire to learn more about local culture and history. While some sites remain "off limits" to tourists, and comprehensive maps of the cultural sites remain in control of local community leaders, there have been efforts to inform tourists about sites that are available; these include visible maps on signs in certain places, as well as information on publicly available websites catering to foreign tourists. Guides have been trained in safety as well as historical and cultural information that deepen tourists' knowledge about and connection to the landscapes they traverse. These current movements across international boundaries follow historical routes and continue to link communities, highlighting and cementing ancestral cultural ties while also providing income opportunities on both sides of the border. 


\section{REFERENCES}

Amster, M. (2009). Portable potency: Christianity, mobility and spiritual landscapes among the Kelabit, Anthropological Forum, 19(3), 307-322. https://10.1080/00664670903278429

Amster, M. (1998). 'Tradition,' ethnicity, and change: Kelabit practices of name changing. Sarawak Museum Journal, Vol. LIV (No. 75 New Series), 183-200.

Ardhana, I.K., Langub, J. and Chew, D. (2004). Borders of kinship and ethnicity: Cross-border relations between the Kelalan Valley, Sarawak, and the Bawan Valley, East Kalimantan. Borneo Research Bulletin, 35, 144-179.

Bala, P. (2002). Changing borders and identities in the Kelabit Highlands: Anthropological reflections on growing up near an international border (No. 1). Unit Penerbitan Universiti Malaysia Sarawak.

Bala, P. (2009). An engagement with modernity? Becoming Christian in the Kelabit Highlands of Central Borneo. Borneo Research Bulletin, 40, 173-185.

Barker, G. (2008, September 26). Footsteps and marks: transitions to farming in the rainforests of Island Southeast Asia. Program in Agrarian Studies (pp.3-16), Yale University.

Blust, R.A. (1974). A double counter-universal in Kelabit. Paper in Linguistics, 7(3-4), 309-324. https://doi.org/10.1080/08351817409370376

Bulan, R. (2003). Boundaries, territorial domains, and Kelabit customary practices: discovering the hidden landscape. Borneo Research Bulletin, 34, 18-61.

Carrier, J.G., and Macleod, D.V.L. (2005). Bursting the bubble: The socio-cultural context of ecotourism. Royal Anthropological Institute, 11, 315-334. https://doi.org/10.1111/j.14679655.2005.00238.x

Chin, C.L.M., Moore, S.A., Wallington, T.J. and Dowling, R.K. (2000). Ecotourism in Bako National Park, Borneo: Visitors' perspectives on environmental impacts and their management. Journal of Sustainable Tourism, 8(1), 20-35. https://doi.org/10.1080/09669580008667347

Cluny, W. and Chai., P. (2007). Cultural sites of the northern highlands Sarawak, Malaysia: Megaliths and burials. ITTO Project PD 224/03 Rev. 1(F): Transboundary biodiversity conservation Pulong Tau National Park. International Tropical Timber Organization and Sarawak Forest Department.

Coates, K. (2014). The landscape of memory: Archaeology, oral history, and culture deep in the Malaysian jungle. Archaeology, March/April 2014, 55-61. https://www.archaeology.org/issues/1271403/letter-from/1793-borneo-jungle-megalithic-mounds-stone-jars

Din, K.H. (1997). Tourism and cultural development in Malaysia: Issues for a new agenda. In S. Yamashita, K.H. Din, and J.S. Eades (Eds.), Tourism and cultural development in Asia and Oceania (pp. 104-118). Penerbit Universiti Kebangsaan Malaysia.

Douglas, R.S. (1912). An expedition to the Bah Country of central Borneo. Sarawak Museum Journal, 1(2), 17-30.

Eghenter, C. and Langub, J. (2008). Past meets future: A transborder forum for a sustainable future for the highlands of Borneo. Borneo Research Bulletin, 39, 286-294.

Eliade, M. (1979). A history of religious ideas. Collins Publishers. 
FORMADAT. (2020). FORMADAT \& UNDP hold symposium to commemorate Equator prize win. https://formadat.org/news/formadat-undp-hold-symposium-to-commemorate-equator-prize-win/

Gani, N. (2019). Megalithic sites in Punang Kelapang, Upper Baram, Sarawak: A preliminary survey. Jurnal Arkeologi Malaysia, 32(2), 13-30.

Harris, R. (2002). Electronic commerce for community-based pro-poor tourism (proposal to infoDev Core program for e-tourism project in the Kelabit Highlands of Sarawak). http://rogharris.org/Etourism\%20proposal.pdf

Harrisson, T. (1973). Megalithic evidences in East Malaysia: An introductory summary. Journal of the Malaysian Branch, Royal Asiatic Society, XLVI, Part 1, 123-140.

Harrisson, T. (1962). Megaliths of central Borneo and western Malaya, compared." Sarawak Museum Journal, XI (19-20) (New Series), 376-382.

Harrisson, T. (1959). More 'megaliths' from inner Borneo. Sarawak Museum Journal, IX(13-14), 1420.

Harrisson, T. (1958a). A living megalithic in upland Borneo. Sarawak Museum Journal, VIII(12) (New Series), No. 29 (Old Series), 694-702.

Harrisson, T. (1958b). Megaliths of Central and West Borneo. Sarawak Museum Journal, VIII(11) (New), No. 26 (Old), 394-401.

Harrisson, T. (and Penghulu Balang Siran). (1959). World within: A Borneo story. Oxford University Press.

Hitchner, S. (2010). Heart of Borneo as a 'jalan tikus': Exploring the links between indigenous rights, extractive and exploitative industries, and conservation at the World Conservation Congress 2008. Conservation and Society, 8(4), 320-330. https://doi.org/10.4103/0972-4923.78148

Hitchner, S. (2009a). Remaking the landscape: Kelabit engagements with conservation and development. (Doctoral Dissertation, University of Georgia).

Hitchner, S. (2009b). The living Kelabit landscape: Documenting and preserving cultural sites and landscape modifications in the Kelabit Highlands of Sarawak, Malaysia. Sarawak Museum Journal, LXVI (87), 1-79.

Hitchner, S., Apu, F.L., Galih, S., Tarawe, L. and Yesaya, E. (2009). Community-based transboundary ecotourism in the heart of Borneo: A case study of the Kelabit Highlands of Malaysia and the Kerayan Highlands of Indonesia. Journal of Ecotourism, 8(2), 193-213. https://doi.org/10.1080/14724040802696064

Hose, C. (1900). In the Heart of Borneo. The Geographical Journal, 16(1), 39-59.

Ismail, G. (1998). Introduction: Bario: The Highland of the Kelabit People. In I. Ghazally and L. Bin Din (Eds.), A scientific journey through Borneo: Bario, The Kelabit Highlands of Sarawak. (pp. i-iii). Pelanduk Publications.

Jalong, P.N. (1989). The Ngurek. Sarawak Museum Journal, XL(61) (Special Issue 4/III), 157-168.

Janowski, M. and Barton, H. (2012). Reading human activity in the landscape. Indonesia and the Malay World, 40(118), 354-371. https://doi.org/10.1080/13639811.2012.709005 
Jones, S.E., Barton, H., Hunt, C.O., Janowski, M., Lloyd-Smith, L. and Barker, G. (2016). The cultural antiquity of rainforests: Human-plant associations during the mid-late Holocene in the interior highlands of Sarawak, Malaysian Borneo. Quaternary International, 416, 80-94. https://doi.org/10.1016/j.quaint.2015.11.024

Keith, H.G. (1947). Megalithic remains in North Borneo. Journal Malayan Branch, Royal Asiatic Society. $X X$, part I, 153-155.

King, V.T. (1993). Tourism and culture in Malaysia. In M. Hitchcock, V.T. King, and J.G. Parnwell (Eds.), Tourism in Southeast Asia (pp. 99-116). Routledge.

Labang, L. (1962). "Married megaliths" in upland Kalimantan. Sarawak Museum Journal, XI(19-20) (New Series), 383-385.

Langub, J. (1987). Ethnic self-labelling of the Murut or Lun Bawang of Sarawak. Journal of Social Issues in Southeast Asia, 2, 289-299. https://www.jstor.org/stable/41056733

Lonely Planet (2020). Kelabit Highlands in detail: Trekking. https://www.lonelyplanet.com/a/nar/0b830465-1756-4355-8765-7c648fd0a39d/1321702

Mashman, V. (2017). Stones and power in the Kelapang: Indigeneity and Kelabit and Ngurek narratives. In V. King, Z. Ibrahim, and N. H. Hassan (Eds.), Borneo Studies in History, Society and Culture (pp. 405-426). Springer.

McLaren, D. (1997). Rethinking tourism and ecotravel: The paving of paradise and what you can do to stop it. Kumarian Press.

Mjöberg, E. (1925). An expedition to the Kalabit Country and Mt. Murud, Sarawak. Geographical Review, 15(3), 411-427.

Mohamed, B. (2002). The development of tourism in Malaysia: Is it really sustainable? Paper presented at the International Year of Ecotourism 2002: Community-based ecotourism in Southeast Asia, Chiang Mai, Thailand.

Mowforth, M. and Munt, M. (1998). Tourism and sustainability: New tourism in the third world. Routledge.

Phelan, P.R. (1997). Traditional stone and wood monuments of Sabah. Pusat Kajian Borneo.

Reed, M.G. (1997). Power relations and community-based tourism planning. Annals of Tourism Research, 24(3), 566-591. https://doi.org/10.1016/S0160-7383(97)00023-6

Richter, L.K. (1989). The politics of tourism in Asia. University of Hawaii Press.

Saging, R.L. (1976/77). An Ethno-History of the Kelabit Tribe in Sarawak: A Brief Look at the Kelabit Tribe Before World War II and After. Unpublished thesis submitted to the Jabatan Sejarah, University of Malaya for Degree in Bachelor of Arts.

Saging, R.L. and Bulan, L. (1989). Kelabit ethnography: A brief report. Sarawak Museum Journal, $\mathrm{XL}(61), 89-118$.

Scheyvens, R. (1999). Ecotourism and the empowerment of local communities. Tourism Management, 20(2), 245-249. https://doi.org/10.1016/S0261-5177(98)00069-7 
Schneeberger, W. (1945). The Kerayan-Kalabit Highland of central northeast Borneo. Geographical Review, 544-562.

Sellato, B. (2016). The Ngorek of the central highlands and 'megalithic' activity in Borneo. In C. Jeunesse, P. Le Roux, \& B. Boulestin (Eds.), Living and past megalithisms: Interwoven approaches (pp. 117-150). Archaeopress. https://doi.org/10.2307/j.ctvxrq101.11

Sidu, J. (2007). A socio-economic study of the communities living adjacent to the Pulong Tau National Park. Transboundary Biodiversity and Conservation Area: The Pulong Tau National Park, Sarawak State, Malaysia, Serial number PD 224/03 Rev. 1 (F). International Tropical Timber Organization, Sarawak Forest Department \& Sarawak Forestry Corporation.

Singh, H. (1998). The physiography and general geology of the Kelabit Highlands surrounding the Bario area. In G. Ismail and L. Bin Din (Eds.), A Scientific Journey through Borneo: Bario, The Kelabit Highlands of Sarawak (pp. 1-20). Pelanduk Publications.

Stronza, A. (2001). Anthropology of tourism: Forging new ground for ecotourism and other alternatives. Annual Review of Anthropology, 30, 261-83. https://doi.org/10.1146/annurev.anthro.30.1.261

Talla, Y. (1978). The Kelabit of the Kelabit Highlands, In C. Sather (Ed.) Sarawak Report No. 9. Universiti Sains Malaysia.

Tan, C.B. (1994). Kelabit associations. In C.B. Tan (Ed.) Communal Associations of the Indigenous Communities of Sarawak: A Study of Ethnicity and National Integration (pp. 116-140). Institute for Advanced Studies, University of Malaya.

Von Koenigswald, G.H.R. (1962). A remarkable megalith and gold ear-ring from Java. Sarawak Museum Journal, XI(19-20) (New Series), 372-375.

West, P. and Carrier, J. (2004). Ecotourism and authenticity: Getting away from it all? Current Anthropology, 45(4), 483-498. https://doi.org/10.7916/D88W3BD4

World Wide Fund for Nature (WWF) Denmark, in collaboration with WWF Indonesia (2006). In L. Topp and C. Eghenter (Eds.), Kayan Mentarang National Park: In the Heart of Borneo. World Wide Fund for Nature.

Yacob, M.R., Shuib, A., Mamat, M.F. and Radam, A. (2007). Local economic benefits of ecotourism development in Malaysia: The case of Redang Island Marine Park. International Journal of Economics and Management, 1(3), 365-386.

Zainuri, L.H. (2018). Dayak Lundayeh: A report from the border. CLCWeb: Comparative Literature and Culture, 20.2, https://doi.org/10.7771/1481-4374.3233

Zeppel, H. (1997). Meeting 'wild people': Iban cultured longhouse tourism in Sarawak. In S. Yamashita, K.H. Din and J.S. Eades (Eds.), Tourism and cultural development in Asia and Oceania (pp. 119-140). Penerbit Universiti Kebangsaan Malaysia. 